DOI: 10.46340/eppd.2020.7.2.39

Тетяна Приступенко, к. і. н. Київський національний університет імені Тараса Шевченка, Україна ПРОФЕСІЙНІ СТАНДАРТИ ЖУРНАЛІСТІВ ЯК КАТЕГОРІЯ СОЦІАЛЬНӦ̈ ВІДПОВІДАЛЬНОСТІ МЕДІЙ В ГРОМАДЯНСЬКОМУ СУСПІЛЬСТВІ

\author{
Tetiana Prystupenko, PhD in History \\ ORCID ID: https://orcid.org/0000-0001-9546-8228 \\ Taras Shevchenko National University of Kyiv, Ukraine

\section{PROFESSIONAL STANDARDS OF JOURNALISTS AS A CATEGORY OF SOCIAL RESPONSIBILITY OF MEDIA IN THE CIVIL SOCIETY}

The content of professional standards of Ukrainian journalism and their correlation with legal norms are revealed. The professional standards of news journalism in Ukraine are compared with the editorial values of the BBC, the necessity of supplementing the national professional standards with the provisions on materials about children as a specific audience is substantiated. The problems of lack of responsibility for violation of professional standards of journalists and the difficulty of adherence to professional standards due to pressure from media owners are highlighted. The necessity of taking into account the legislation on the media realities of the development of digital technologies and the emergence of new channels of communication and establishing responsibility for violating the professional standards of journalists by strengthening the regulation of compliance with editorial charters was proved.

Keywords: media, journalism, professional standards of journalists, journalistic ethics, social responsibility.

Постановка проблеми. Сучасний період для України характеризується високим рівнем турбулентності усіх сфер громадського життя. Виступаючи в якості «четвертої влади», вітчизняні засоби масової інформації несуть значну відповідальність за збереження держави та об'єднання суспільства.

Інформація $є$ вагомим інструментом впливу на соціальну свідомість, а засоби масової комунікації виступають потужним знаряддям формування моделі суспільних відносин та суспільної думки, що робить їх одним з найважливіших соціальних інститутів. Новітні технології в сфері масових комунікацій додатково посилюють роль медій в житті суспільства. Висока соціальна роль медій в громадянському суспільстві обумовлює необхідність не тільки регулювання їх діяльності, а й формування принципів та засадничих вимог щодо висвітлення інформації - комплексу професійних та етичних стандартів журналістів.

Аналіз останніх досліджень та публікацій. Питання дотримання професійних стандартів журналістської діяльності в роботі сучасних медій є комплексним та пов'язане 3 вивченням науковоаналітичних матеріалів в сфері соціальних комунікацій, соціології, етики, юриспруденції, міжнародних відносин. Дослідженню масових комунікацій та соціальної ролі медій присвячені роботи таких авторів, як Ф.С. Сіберт, Т. Петерсон, У. Шрамм, С.М. Квіт. Юридичні аспекти імплементації професійних стандартів журналістської діяльності у вітчизняне законодавство детально вивчалися Р.Головенком. Питання використання професійних стандартів в діяльності журналістів розглянуто В.С. Литвиним, Н. Фенько, Д. Чоповським, С.В. Штурхецьким.

Розробка рекомендацій та вивчення практики дотримання професійних стандартів та порушень журналістської етики здійснюється Національною радою України з питань телебачення i радіомовлення (Нацрадою), а також міжнародними та національними громадськими організаціями (ОБСЄ, Інститутом масової інформації, ГО «Детектор медіа», Комісією з журналістської етики, Незалежною медійною радою та ін.). 
Метою проведення дослідження визначено оцінку існуючого стану та перспектив посилення дотримання професійних стандартів журналістів як категорії соціальної відповідальності медій в громадянському суспільстві.

Виклад основного матеріалу дослідження. Наявність потужного впливу засобів масової інформації на суспільну свідомість та процеси формування громадської думки $є$ незаперечним фактом. Медії здатні моделювати та програмувати поведінку людей, тим самим впливаючи на довгострокові перспективи розвитку суспільства. При цьому, наслідки такого впливу можуть мати як позитивний характер (усебічний розвиток особистості, пропагування моральності та високих культурних цінностей), так і бути негативними (насаджування стереотипів, надмірне інформаційне навантаження, пропагування викривлених моделей поведінки тощо).

Основи концепції соціальної відповідальності медій були розроблені американськими соціологами Ф. С. Сібертом (F.S. Siebert), Т. Петерсоном (T.Peterson) та У. Шраммом (W. Schramm) у 1956 р. в рамках «чотирьох теорій преси», та базувалися на консолідації суспільного контролю функціонування медій з одночасним збереженням свободи слова. Інструментарієм реалізації такого поєднання, на думку авторів, мало стати формування незалежних суспільних інститутів регулювання 3МІ з одночасним підвищення професіоналізму журналістів та дотриманням професійних стандартів.

Професійні стандарти журналістики як умова забезпечення соціальної відповідальності 3МI не втрачає актуальності і для роботи сучасних медій. У більшості цивілізованих країн прийнято кодекси або правила, що закріплюють етичні засади та професійні стандарти здійснення журналістської діяльності. Серед загальних журналістських етичних кодексів, які набули міжнародного визнання та прийняті міжнародними організаціями журналістів, доцільно виділити:

1. Декларацію принципів поведінки журналістів Міжнародної федерації журналістів (МФЖ), прийняту на II всесвітньому Конгресі МФЖ (Бордо, 25-28 квітня 1954 р.), зі змінами, прийнятими на 18-му всесвітньому Конгресі МФЖ (Хельсингьор, 2-6 червня 1986 р.).

2. Міжнародні принципи журналістської етики, ухвалені на IV Консультативній зустрічі міжнародних і регіональних журналістських організацій (1983р.).

3. Резолюцію Парламентської Асамблеї Ради Європи «Про етичні принципи журналістики» (1993 р.).

У якості прикладів національних журналістських етичних кодексів В.П. Мостовий та В.В. Різун наводять Кодекс професійної етики Товариства професійних журналістів SPJ (США, 1996 р.), Декларацію принципів Американського товариства редакторів газет ASNE (США, 1975 р.), Публіцистичні засади (Німеччина, 2001 р.), Принципи поведінки для преси, радіо, телебачення та поліції (Німеччина, 1993 р.), Редакційні настанови Бі-Бі-Сі (Великобританія, 2005 р.), Кодекс журналістської етики Асоціації польських журналістів SDP (Польща, 1995 р.), Кодекс етики журналіста (Чехія, 1999 р.), Кодекс професійної етики російського журналіста (Росія, 1994 р.).

Досліджуючи етичні засади в журналістиці, В.С. Литвин відзначає наявність професійноетичних стандартів журналістів окремих міст, сфер діяльності, редакцій (редакційні статути, настанови, стандарти).

Головними нормативними документами, де відображені професійні стандарти вітчизняної журналістики, є Декларація принципів поведінки журналістів МЖУ, інші міжнародні стандарти і принципи журналістської етики, Кодекс етики українського журналіста (затверджений у 2013 р. та складається з19 положень), Професійні стандарти новинної та аналітичної журналістики, Рекомендації щодо висвітлення виборів засобами масової інформації та захисту права на приватне життя (розроблені експертами Ради Європи та доопрацьовані вітчизняною медійною спільнотою). Для телерадіоорганізацій Законом України «Про телебачення i радіомовлення» встановлено необхідність прийняття редакційного статуту, для інших видів медій такий документ не є обов'язковим.

Професійні стандарти української журналістики лишаються етичними питаннями, оскільки у вітчизняному законодавстві вони згадуються лише побіжно (зокрема, вимоги до об'єктивності та достовірність поширюваної інформації представлені уст. 59 та ст. 60 Закону України «Про телебачення і радіомовлення», ст. 26 Закону України «Про друковані засоби масової інформації (пресу) в Україні»). Проте варто зазначити, що хоча етичні кодекси журналістської діяльності не мають юридичної сили, однак діяльність журналістів та медіа здійснюється у правовому полі. Відповідно зловживання свободою слова може тягнути за собою адміністративну, цивільну чи кримінальну відповідальність. 
Досліджуючи особливості регулювання журналістської етики та професійних стандартів українським законодавством, юрист Інститут масової інформації (IMI) Р. Головенко наголошує на номінальності редакційних статутів через відсутність реального нагляду за їх виконанням. Хоча редакційні ради теле- та радіоканалів, на яких покладено функції контролю виконання редакційних статутів, формуються з представників власника та творчого колективу, однак в українських медіа редакційна політика зазвичай диктується саме інтересами власника. Змінити таку ситуацію може встановлення тристороннього принципу формування редакційних рад за рахунок включення до них представників незалежних журналістських експертних об'єднань.

Аналізуючи найновіший західний та український досвід, С.М. Квіт відзначає, що в якості еталону професійних стандартів журналістів часто приймаються Редакційні цінності Бі-Бі-Сі, зокрема:

- правдивість і точність подачі інформації;

- безсторонність і багатоманітність точок зору;

- редакційна чесність і незалежність;

- служіння суспільним інтересам;

- справедливість, недоторканність приватного життя;

- врівноваження права на передачу і публікацію нової та суперечливої інформації 3 відповідальністю стосовно захисту вразливих людей;

- сприйняття дітей як специфічної авдиторії, що вимагає власного комплексного підходу;

- підзвітність перед авдиторією.

Професійні стандарти новинної та аналітичної журналістики в Україні, визначені експертами IMI та іншими медійними громадськими організаціями, перегукуються зі стандартами світових мовників. Такими стандартами є:

1. Дотримання балансу думок та точок зору задля всебічного висвітлення подій. Важливою умовою дотримання цього стандарту $\epsilon$ неупередженість самого журналіста, відсутність маніпулювання думкою експертів та відображення всіх сторін при висвітленні конфліктних ситуацій.

2. Оперативність та актуальність висвітлення подій (за умови дотримання решти стандартів).

3. Достовірність інформації, використання ідентифікованих та надійних джерел (анонімність джерела можлива за умови загрози його життю, здоров'ю чи професійній діяльності). Перевірка інформації, отриманої із анонімних та ідентифікованих джерел.

4. Відокремлення фактів та коментарів експертів від коментарів власне журналіста.

5. Точність поширюваної інформації. Спростування неправдивої інформації максимально швидко після того, як про це стало відомо.

6. Повнота повідомлення.

Дослідження дотримання професійних стандартів новинної журналістики на регулярній основі проводиться Інститутом масової інформації, ГО «Детектор медіа» та Комісією з журналістської етики. Так, за результатами досліджень 17 загальнонаціональних інтернет-3МІ у січні 2020 р., рівень дотримання професійних стандартів істотним чином відрізняється - якщо 98\% матеріалів видань «Український тиждень», Укрінформ, «Ліга», «Дзеркало тижня» та «Українська правда» не містили порушень професійних стандартів журналістики, то на сайті «Знай.юа» таких матеріалів було лише $14 \%$. Стосовно загального дотримання професійних стандартів в досліджуваних 3МI, то часто спостерігалося не відокремлення фактів від коментарів (порушення містили $10 \%$ публікацій) та порушення стандарту достовірності (у 7,5\% публікацій). Найкращим в онлайн-медіа протягом січня 2020 р. було дотримання балансу думок (порушення містили лише 5,5\% матеріалів).

Порівнюючи означені професійні стандарти новинної журналістики із редакційними цінностями Бі-Бі-Сi, варто наголосити на відсутності положення щодо дітей як окремої глядацької аудиторії. Після низки скандально-дискусійних матеріалів, пов'язаних із висвітленням історій дітей, які опинилися у складних життєвих ситуаціях (зокрема, ток-шоу на телеканалі СТБ «Один за всіх», «Кохана, ми вбиваємо дітей», «Битва екстрасенсів», «Слідство ведуть екстрасенси»), у листопаді 2016 р. трьома найбільшими телегрупами («1+1 медіа», StarLightMedia, «Медіа Група Україна»), суспільним мовником Національна телерадікомпанія України та об'єднанням місцевих і регіональних телерадіокомпаній Незалежна асоціація телерадіомовників було підписано спільний акт узгодження «Захист дитини, яка зазнала сексуального насильства, при залученні до медіа-виробництва». Документ відмовилася підписати телегрупа «Інтер», хоча іiі представники також брали участь у розробці. 
Після виходу резонансного ток-шоу «Інтера» «Стосується кожного» про 12-ти річну породіллю від 09.10.2017 та 13.10.2017 питання коректного висвітлення історій дітей, які опинилися в складних життєвих ситуаціях, знову стали предметом розгляду органів саморегуляції (Незалежної медійної ради та Нацради) та призвели до позапланових перевірок телеканалу «Інтер» за скаргою Омбудсмена та ГО «Детектор медіа».

Погоджуючись 3 позицією Н. Фенько, важливо наголосити, що «коли йдеться про висвітлення історій дітей, які зокрема стали жертвами сексуального насильства, $є$ неприпустимою ідентифікація дитини в матеріалах (називання прізвищ, показ облич, оприлюднення назв населених пунктів тощо). Подібні матеріали не мають нічого спільного із професійною та відповідальною журналістикою, оскільки порушують права дитини й етичні стандарти».

Задля запобігання в подальшому вказаним випадкам доцільно врахувати досвід Бі-Бі-Сі та доповнити професійні стандарти новинної та аналітичної журналістики положенням щодо матеріалів про дітей як специфічної авдиторії. Крім того, варто посилити регулювання Незалежною медійною радою та Нацрадою сюжетів, пов'язаних з гостросоціальними темами щодо неповнолітніх.

Не менш гострим лишається питання особливостей дотримання професійних стандартів під час висвітлення бойових дій. В рамках круглого столу «Стандарти журналістської діяльності під час конфлікту», організованого в грудні 2014 р. Координатором проектів ОБСЄ в Україні, ГО «Детектор медіа» та Комісією з журналістської етики, були розроблені Рекомендації щодо стандартів і етики журналістики в умовах конфлікту та кризових ситуацій. Під егідою ОБСЄ у 2016 р. було видано посібник, який містить передовий досвід та рекомендації щодо журналістики в умовах конфлікту. Проте суспільний консенсус щодо дотримання журналістських стандартів під час війни і досі відсутній. На додаткових загрозах об'єктивному висвітленню інформації через «значне психоемоційне та фізичне навантаженням, яке супроводжується небезпекою для життя та здоров'я», акцентує С.В.Штурхецький. Погоджуючись 3 автором, варто наголосити, що «журналістів можуть використовувати як ретрансляторів вигідних для пропагандистів панічних настроїв, та й журналісти як звичайні люди можуть втрачати рівновагу, коли на їх очах відбуваються драматичні й трагічні події». Тому такі матеріали потребують особливої уваги з боку редакторів щодо відповідності професійним журналістським стандартам.

Суттєвим викликом дотримання професійних стандартів журналістів в українських реаліях стає тиск на медіа з боку власників, чиновників або політиків. В умовах постійних перетрубацій та високої турбулентності соціально-політичної ситуації в українському суспільстві вітчизняні медіа стають інструментами політичної боротьби. Власники ЗМІ активно втручаються в редакційну політику, відтак чого інформація подається із певними викривленнями, що $є$ прямим порушенням як професійних стандартів новинної журналістики, так і п. 2 Кодексу етики українського журналіста «Служіння інтересам влади чи засновників, а не суспільства, $є$ порушенням етики журналіста».

Досліджуючи соціальну відповідність медій та практику дотримання професійних журналістських стандартів, важливим стає формування критеріїв, за якими засоби масової комунікації можуть бути віднесені до ЗМІ. Актуальність такого питання обумовлена зростанням популярності нових засобів передачі інформаційних повідомлень, зокрема Telegram-каналів, YouTube-каналів персональних YouTube-блогів, тощо. Ведучі таких каналів заради популярності та збільшення авдиторії використовують прийоми, що протирічать професійним стандартам журналістики - розміщують неперевірену інформацію, «смажені» факти, використовують нецензурну лексику, а фраза «моє оціночне судження» після матеріалу виконує роль певної індульгенції за порушення всіх професійних стандартів новинної журналістики.

У цьому контексті важливим $є$ акцентування на різниці між блогером та журналістом, яку досить чітко відзначив В.Познер «... (блогер) не несе жодної відповідальності, що хоче, те й говорить. Йому не треба перевіряти факти, він може брехати, все що завгодно. Ніякого контролю на відміну від журналіста».

Додаткову складність регулювання дотримання професійних стандартів в медіа створює і доступність професії - щоб стати журналістом, не обов'язково мати фахову освіту, бути членом професійного об'єднання тощо. Така ліберальність, на думку Р. Головенка, «не дає можливості професійній спільноті реагувати на порушників професійних стандартів шляхом позбавлення їх належності до своєї корпорації або в якихось м'якших формах». Активні реакції Нацради на скарги громадських організацій щодо порушень професійних стандартів в медійному контенті спостерігаються лише останні кілька років. 
Отже, щоб донести інформацію до авдиторії, журналіст має знати та розуміти ситуацію з різних боків (дотримання професійних принципів балансу думок, повноти, достовірності, точності). Натомість блогери не виконують таких функцій, транслюють однобічні позиції, свій суб' єктивний погляд, не аналізують альтернативні точки зору. Логічним $є$ висновок про необхідність формування і у самої авдиторії розуміння відмінності між професійною журналістикою та блогерством, в першу чергу - щодо відповідальності за об'єктивність та достовірність висвітлення інформації.

У якості радикальної спроби врегулювання діяльності блогерів доцільно навести досвід Росії, де в травні 2014 р. було прийнято так званий «Закон про блогерів»- федеральний закон, що зобов'язував власників інтернет-ресурсів (сайтів, блогів, сторінок у соціальних мережах тощо) 3 авдиторією «понад 3000 користувачів на добу» реєструватися в Роскомнагляді. Для власників таких ресурсів були частково встановлені вимоги, передбачені в Росії для ЗМІ. Такі нововведення викликали гостру соціальну реакцію, проте не стали суттєвим механізмом обмеження в мережі Інтернет. У липні 2017 р. «Закон про блогерів» було скасовано.

Вдосконалення роботи різноманітних каналів комунікації та їх актуалізація відповідно до вимог сучасності потребує і вітчизняне нормативно-правове регулювання медійної сфери. Так, внесений до Верховної Ради проект Закону «Про медіа» № 2963 пропонує розширення повноважень Нацради щодо регулювання будь-яких суб'єктів у сфері медій, зокрема й онлайн-медій, телеграм-каналів, блогерів і відеоблогерів. Законопроектом передбачено добровільну реєстрацію онлайн-медій, проте відповідальність за порушення законодавства засоби масової інформації будуть нести незалежно від реєстрації. При цьому, вимоги щодо дотримання професійних стандартів журналістики в проекті Закону № 2963 відсутні, а жодної відповідальності за їх недотримання не передбачено. Варто наголосити, що зазначений законопроект № 2963 стикається з активною критикою з боку журналістської спільноти, представників 3МІ, українських та міжнародних експертів зі свободи слова та регулювання медій.

Напрямом посилення дотримання професійних стандартів журналістики в роботі українських ЗМI є запропоноване юристом IMI Р.Головенком юридичне закріплення необхідності розробки редакційних статутів на базі журналістських стандартів та встановлення відповідальності за відсутність, невиконання або невідповідність редакційних статутів професійним стандартам журналістики.

Законодавчі ініціативи колишнього міністра культури, молоді та спорту В. Бородянського щодо захисту вітчизняного інформаційного простору від дезінформації також викликали гостру негативну реакцію з боку медіа-спільноти. 3 відставкою 4 березня 2020 р. уряду О. Гончарука, В. Бородянський пішов з посади міністра, а міністерство культури, молоді та спорту було розділено на два окремі відомства. Відповідно, питання про подальшу долю законопроєкту із робочою назвою «Про боротьбу 3 дезінформацією» лишається відкритим.

Висновки та перспективи подальших досліджень. Таким чином, дотримання професійних журналістських стандартів у матеріалах сучасних медій є невід'ємною умовою реалізації соціальної відповідальності засобів масової інформації в громадянському суспільстві. Перешкодами цьому стає втручання власників ЗМІ в редакційну політику, заангажованість журналістів (несвідома або усвідомлена), гонитва за рейтингом тощо. Суттєвою проблемою виступає відсутність чіткого нормативно-правового врегулювання відповідальності за порушення професійних стандартів журналістів, невідповідність законодавства про медіа реаліям розвитку цифрових технологій та появі нових каналів комунікацій, надмірна довірливість авдиторії через нерозуміння різниці між вимогами до інформації у 3МІ та відсутністю регулювання контенту телеграм-каналів, блогерів і відеоблогерів.

Перспективами подальших досліджень $є$ визначення практичних напрямів посилення взаємодії між журналістською спільнотою та суспільством щодо пояснення відмінностей між професійною журналістикою та блогерством, особливо в сфері дотримання професійних журналістських стандартів щодо достовірності, об'єктивності та надійності інформації.

\section{References:}

1. Siebert, F. S., Peterson, T., Schramm, W. (1956). Four Theories of the Press. Urbana: University of Illinois Press. [in English]

2. Mostovyj, V.P., Rizun, V.V. (2014). Žurnalists'ka etyka: Posibnyk dlja pidhotovky do deržavnoho ispytu [Journalistic Ethics: A Guide to Preparing for the State Exam]. Kyjiv, TzOV «ZN UA». [in Ukrainian].

3. Lytvyn, V. Je. Etyčni zasady dijal'nosti žurnalistiv u normatyvno-pravovyx dokumentax Ukrajiny. [Ethical Foundations of Journalists' Activities in the Legal Documents of Ukraine] Elektronna biblioteka Instytutu žurnalistyky. [The Electronic Library of the Institute of Journalism]

$<$ http://journlib.univ.kiev.ua/index.php?act=article\&article=2322> [in Ukrainian]. (2020, March, 01) 
4. Kodeks etyky ukrajins'koho žurnalista (2013). [Code of Ethics of Ukrainian Journalist]. Materialy Komisiji z žurnalists 'koji etyky. [Materials of the Journalist Ethics Commission]. <http://www.cje.org.ua/ua/code> [in Ukrainian]. (2020, February, 28)

5. Zakon Pro telebačennja i radiomovlennja st. 57. 1994 (Verxovna Rada Ukrajiny). [Law on Television and Radio Art. 57. 1994 (Verkhovna Rada of Ukraine)]. Oficijnyj sajt Verxovnoji Rady Ukrajiny. [Official site of the Verkhovna Rada of Ukraine]. <https://zakon.rada.gov.ua/laws/show/3759-12> [in Ukrainian]. (2020, February, 28)

6. Zakon Pro telebačennja i radiomovlennja st. 59, st. 60. 1994 (Verxovna Rada Ukrajiny). [Law on Television and Radio Art. 59, Art. 60. 1994 (Verkhovna Rada of Ukraine).]. Oficijnyj sajt Verxovnoji Rady Ukrajiny. [Official site of the Verkhovna Rada of Ukraine]. <https://zakon.rada.gov.ua/laws/show/3759-12> [in Ukrainian]. (2020, March, 01)

7. Zakon Pro drukovani zasoby masovoji informaciji (presu) v Ukrajini st. 26. 1993 (Verxovna Rada Ukrajiny). [The Law on Print Media in Ukraine Art. 26. 1993 (Verkhovna Rada of Ukraine)]. Oficijnyj sajt Verxovnoji Rady Ukrajiny. [Official site of the Verkhovna Rada of Ukraine]. <https://zakon.rada.gov.ua/laws/show/2782-12> [in Ukrainian]. (2020, March, 02)

8. Holovenko, R. Jak žurnalists'ka etyka i standarty rehuljujut'sja zakonamy Ukrajiny. [How journalistic ethics and standards are governed by the laws of Ukraine]. Instytut masovoji informaciji. [Institute of Mass Media]. $<$ https://imi.org.ua/monitorings/yak-zhurnalistska-etyka-i-standarty-rehulyuyutsya-zakonamy-ukrajiny-i28367> [in Ukrainian]. (2020, March, 03)

9. Kvit, S. (2018). Masovi komunikaciji. [Mass communication]. Kyjiv: Vydavnyčyj dim «Kyjevo-Mohyljans'ka akademija». [in Ukrainian].

10. Redakcijni nastanovy Bi-Bi-Si (2005). [BBC Editorial Guidelines]. Elektronna biblioteka Instytutu žurnalistyky. [The Electronic Library of the Institute of Journalism]. <http://journlib.univ.kiev.ua/BBC_Guidelines_Ukr.pdf $>$ [in Ukrainian]. (2020, March, 04)

11. Čopovs'kyj, D. Žurnstandarty: ohljad-2011. [Journal Standards: A Review-2011]. Instytut masovoji informaciji. [Institute of Mass Media]. <https://imi.org.ua/monitorings/jurnalistski-standarti-normativna-dovidka-i28622 > [in Ukrainian]. (2020, March, 04)

12. Zvit z monitorynhu dotrymannja profstandartiv v onlajn-media. Perša xvylja monitorynhu u 2020 roci. [Report on monitoring compliance with professional standards in online media. The first monitoring wave in 2020.]. Instytut masovoji informaciji. [Institute of Mass Media]. <https://imi.org.ua/monitorings/zvit-z-monitoryngudotrymannya-profstandartiv-v-onlajn-media-persha-hvylya-monitoryngu-u-2020-rotsi-i31632> [in Ukrainian]. (2020, March 05)

13. Vysnovok Nezaležnoji medijnoji rady ščodo zmistu rozvažal'nyx peredač ta anonsiv na telekanali STB. Vysnovok \# 18, m. Kyjiv, 9 žovtnja 2017 r. [Opinion of the Independent Media Council on the content of entertainment programs and announcements on STB. Opinion No. 18, Kyiv, October 9, 2017]. HO «Detektor media». [Media Detector NGO]. <https://detector.media/community/article/130759/2017-10-10-visnovoknezalezhnoi-mediinoi-radi-shchodo-zmistu-rozvazhalnikh-peredach-ta-anonsiv-na-telekanali-stb/ > [in Ukrainian]. (2020, March, 05)

14. Telekanaly pohodyly spil'ni pravyla vysvitlennja temy seksual'noho nasyl'stva nad dit'my. [TV channels have agreed on common rules on the coverage of the issue of child sexual abuse.]. HO «Detektor media». [Media Detector NGO]. <https://detector.media/community/article/120891/2016-11-24-telekanali-pogodili-spilni-pravilavisvitlennya-temi-seksualnogo-nasilstva-nad-ditmi/ > [in Ukrainian]. (2020, March, 05)

15. «Inter» ne vraxuvav prava 12-ričnoji porodilli pry pokazi šou «Stosujet'sja kožnoho» - Nezaležna medijna rada. [Inter did not take into account the rights of a 12-year-old woman in childbirth when showing the show "Concerns Everyone" - Independent Media Council.]. HO «Detektor media». [Media Detector NGO].

$<$ https://detector.media/community/article/131179/2017-10-23-inter-ne-vrakhuvav-prava-12-richnoi-porodilli-pripokazi-shou-stosuetsya-kozhnogo-nezalezhna-mediina-rada/ > [in Ukrainian]. (2020, March, 06)

16. Fen'ko, N. Pjat' zapytan' kropyvnyc'kym žurnalistam pro profesijni standarty. [Five Questions to Professional Journalists About Kryvyi Rih.]. HO «Detektor media». [Media Detector NGO]

$<$ https://ms.detector.media/profstandarti/post/20121/2017-11-30-pyat-zapitan-kropivnitskim-zhurnalistam-proprofesiini-standarti/ > [in Ukrainian]. (2020, March, 06)

17. Standarty i etyka žurnalistyky v umovax konfliktu ta kryzovyx sytuacij. Rekomendaciji. [Standards and Ethics of Journalism in Conflict and Crisis. Recommendations]. HO «Detektor media». [Media Detector NGO]. $<$ https://ms.detector.media/profstandarti/post/12146/2014-12-19-standarti-i-etika-zhurnalistiki-v-umovakhkonfliktu-ta-krizovikh-situatsii-rekomendatsii/ > [in Ukrainian]. (2020, March, 06)

18. Buromen'skyj, M., Šturxec'kyj, S., Bilz, E., Betc, M., Šjupp, K., Kazanžy, Z. (2016). Žurnalistyka v umovax konfliktu: peredovyj dosvid ta rekomendaciji: Posibnyk rekomendacij dlja pracivnykiv ZMI. [Conflict Journalism: Best Practices and Recommendations: A Guide for Recommendations for Media Workers.]. K.: «Kompanija VAITE». [in Ukrainian].

19. Šturxec'kyj, S. V. (2016). Osoblyvosti dotrymannja žurnalists'kyx standartiv pid čas vysvitlennja bojovyx dij. [Features of observance of journalistic standards in coverage of hostilities]. Informacijne suspil'stvo. [Information Society]. no. 23, 25-30. [in Ukrainian]. 
20. Pozner, V. (2016) O tom, pochemu bloger ne zhurnalist. [About why a blogger is not a journalist]. Pozner Online. [Posner Online]. <https://pozneronline.ru/2016/03/14893/> [in Russian]. (2020, March, 10)

21. Federal'nyj zakon $O$ vnesenii izmenenij v Federal'nyj zakon «Ob informacii, informacionnyh tehnologijah $i$ o zashhite informacii» $i$ otdel'nye zakonodatel 'nye akty Rossijskoj Federacii po voprosam uporjadochenija obmena informaciej s ispol 'zovaniem informacionno-telekommunikacionnyh setej» ot 05.05.2014 № 97-FZ. 2014 (Gosudarstvennaja Duma RF). [Federal Law On Amendments to the Federal Law “On Information, Information Technologies and Information Protection" and certain legislative acts of the Russian Federation on streamlining information exchange using information and telecommunication networks "dated 05.05.2014 No. 97-Ф3. 2014 (State Duma of the Russian Federation)]. «Konsul'tant Pljus»: zakonodatel'stvo RF. ["Consultant Plus": the legislation of the Russian Federation.]. < http://www.consultant.ru/document/cons_doc_LAW_162586/> [in Russian]. (2020, March, 10)

22. Federal'nyj zakon $O$ vnesenii izmenenij $v$ Federal'nyj zakon «Ob informacii, informacionnyh tehnologijah $i$ o zashhite informacii ot 29.07.2017 N 276-FZ. 2017 (Gosudarstvennaja Duma RF). [Federal Law On Amendments to the Federal Law "On Information, Information Technologies and Information Protection of 07.29.2017 N 276-Ф3. 2017 (State Duma of the Russian Federation).]. «Konsul'tant Pljus»: zakonodatel'stvo RF. ["Consultant Plus": the legislation of the Russian Federation.]. $<$ http://www.consultant.ru/document/ cons_doc_LAW_221230/> [in Russian]. (2020, March, 10) [in Russian]. (2020, March, 10)

23. Za zakonom pro media blohery ta nezarejestrovani onlajn-media tež rehuljuvatymut'sja Nacradoju. [The law on media bloggers and unregistered online media will also be regulated by the National Council]. Instytut masovoji informaciji. [Institute of Mass Media]. <https://imi.org.ua/news/za-zakonom-pro-media-blogery-tanezareyestrovani-onlajn-media-tezh-regulyuvatymutsya-natsradoyu-i31464> [in Ukrainian]. (2020, March, 10)

24. Malynka, V. Zakonoprojekt «Pro media»: za ščo joho krytykujut' u zviti OBSJe i jak proponujut' vdoskonalyty. [The Media Law: What it is criticized in the OSCE report and how it is proposed to be improved.]. HO «Detektor media». [NGO Media Detector]. <https://detector.media/infospace/article/175403/2020-03-10-zakonoproekt-promedia-za-shcho-iogo-kritikuyut-u-zviti-obse-i-yak-proponuyut-vdoskonaliti/ > [in Ukrainian]. (2020, March, 10)

25. Holovenko, R. Zakonoprojekt pro media: bez zhadok pro žurnalists'ki standarty. [Media Bill: No mention of journalistic standards.]. $H O$ «Detektor media». [NGO Media Detector]. $<$ https://detector.media/withoutsection/article/174476/2020-02-04-zakonoproekt-pro-media-bez-zgadok-prozhurnalistski-standarti/ > [in Ukrainian]. (2020, March, 10)

26. Urjad lyšyvsja bez ministriv kul'tury ta osvity. [The government was left without ministers of culture and education]. HO «Detektor media». [NGO Media Detector]. <https://detector.media/infospace/article/175292/202003-04-uryad-lishivsya-bez-ministriv-kulturi-ta-osviti/ > [in Ukrainian]. (2020, March, 10) 